\title{
EXPERIMENTAL OCULAR CHLAMYDIAL STUDIES IN LAMBS
}

\author{
P. N. DHINGRA and V. M. MAHAJAN* \\ Department of Veterinary Bacteriology and Virology, College of Veterinary Science, Punjab \\ Agricultural University, Ludhiana, India-141004
}

Received December 27, 1990

\begin{abstract}
Dhingra P. N., V. M. Mahajan: Experimental Ocular Chlamydial Studies in Lambs. Acta vet. Brno, 60, 1991: 345-349.

Two locally isolated strains of Chlamydia psittaci from sheep and cattle and a Bour strain of Chlamydia trachomatis were instilled onto conjunctiva of 6 lambs. Clinical and laboratory investigations were carried out till 52 day post inoculation. Bour strain did not infect the conjunctiva of lambs. However, both the strains of C. psittaci produced follicles on the lower and upper conjunctiva of lambs during the period varying from 1-4 weeks post infection. Pannus or keratitis was neither observed with human nor animal strains. Laboratory studies which included reisolation, fluorescent staining, cytology and serology were negative throughout with Bour strain while positive at one time or the other with $2 \mathrm{C}$. psittaci strains during the period of study.
\end{abstract}

Chlamydia psittaci, Chlamydia trachomatis (Bour), follicles, cytology, fluorescent staining, reisolation

The pathogenic role of Chlamydia psittaci in several diseases of domestic animals is well established. Ocular infection due to Chlamydia psittaci in sheep frequently has been reported to occur in association with epizootic of polyarthritis (Hopkin et al. 1973). Direct evidence of Chlamydia psittaci in ocular infection of man has also been reported (Schachter et al. 1969). The present study, therefore, was undertaken to screen the laboratory tests in the diagnosis of ocular chlamydiosis and the role of different strains of chlamydiae in ocular infection of animals using lambs as model.

\section{Materials and Methods}

Animals

Six healthy lambs aged between $1-2$ months were quarantined for 10 days. Eyes were examined for folliculosis, sub-acute and chronic conjunctivitis, congestion and corneal opacity or vascularization. Serum was tested for circulating antibodies to chlamydia. They were divided into three groups of 2 animals each. Three eyes in each group were used for experimental infection and the fourth was kept as control.

Seed material

Two locally isolated strains of Chlamydia psittaci (faecal strain isolated from normal sheep and another conjunctival strain isolated from an outbreak of follicular conjunctivitis in Holstein heifers) and a Bour strain of Chlamydia trachomatis (obtained from Dr. R. P. Centre for Ophthalmic Sciences, New Delhi) were used. Stock $20 \%$ inoculum of each strain of chlamydia was prepared

Research was done at Section of Ocular Microbiology, All India Institute of Medical Sciences, New Delhi.

* Formerly, Associate Professor, Ocular Microbiology, All India Institute of Medical Sciences, New Delhi. 
from yolk sac membranes rich in elementary bodies in sucrose phosphate glutamate (SPG) medium (Bovarnick et al. 1950). It was centrifuged 2 to 3 times to remove maximum amount of fat and tissue debris. The supernatant collected was titrated in yolk sac of embryonated hens eggs and $\mathrm{ELD}_{5_{0}}$ was calculated. Similarly $20 \%$ normal yolk sac suspension was prepared and used as control antigen. An inoculum of $0.2 \mathrm{ml}$ per eye was used.

Experimental infection

Before infection, xylocain ( $4 \%$ ) drops were instilled into each eye 4 to 5 times at every 5 minutes interval. Three eyes (lamb No. 1 both eyes and lamb No. 2 right eye) were gently scraped on both upper and lower conjunctiva. Bour strain of $C$. trachomatis with $\mathrm{ELD}_{50} 10^{3-6} / 0.2 \mathrm{ml}$ was instilled into each test eye. Both lids were closed for 3 to 5 minutes to avoid drainage of inoculum whenever necessary. Similarly, normal yolk sac suspension as control antigen was instilled into the left eye (lamb No. 2) kept as control. The procedure of inoculation in other two groups of lambs was the same except that Chlamydia psittaci ocular origin with ELD $_{50} 10^{4.5} / 0.2 \mathrm{ml}$ (lamb $3,4)$ and $C$. psittaci faecal origin wit $1 \mathrm{ELD}_{50} 10^{3.6} / 0.2 \mathrm{ml}$ (lamb 5, 6) was inoculated. Animals infected with the three strains were kept separately and the follow-up studies included clinical examination of each eye, cytology ( $\mathrm{Hardy}$ et al. 1957), complement fixation test (Lennette and Schmidt, 1979), reisolation (from pooled conjuctival swabs) and fluorescent staining (Kawamura 1969; Helbert et al. 1972) of appropriate samples collected on 10th, 20th and 52nd day post inoculation (DPI). One animal inoculated with ocular strains of Chlamydia psittaci developed arthritis and the joint fluid was collected for reisolation of chlamydia.

\section{Results}

Out of the three eyes inoculated with Bour strain, none showed true trachomatous follicles. However, mild to acute congestion was noticed during the period of observation. Control eye showed initial congestion only. Laboratory findings were negative except for serology in one animal where CF antibody titre 1:16 was recorded. The pre-test serum of this animal, however was negative. Both the animal strains afier inucolation exhioited initial slight lid oedema, moderate to mild conjunctival congestion and trachoma-like follicles. In majority of the eyes conjunctival follicles were consistently seen between the period of $1-4$ weeks involving both upper and lower conjunctiva including the third eyelid (Fig. 1).

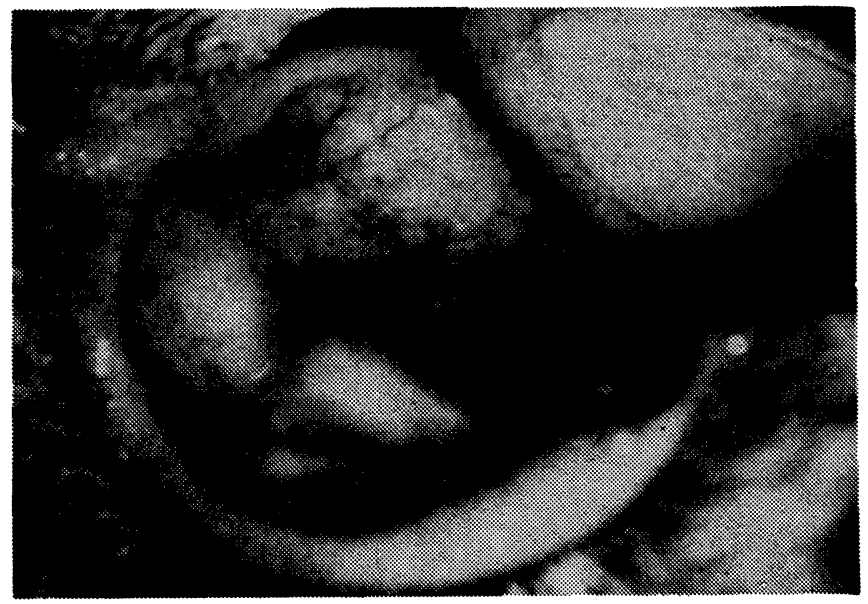

Fig. 1. Congestion and papillary hyperplasia of conjunctiva and third eyelid in a lamb after 2-4 weeks following scarification with strain of Chlamydia psittaci. Slit lamp, $\times 3$. 
Control ey es after initial mild congestion became normal after 7 days. In the animal which developed polyarthritis, reisolation of chlamydia from joint fluid could not be attempted. Reisolation of chlamydia was possible from the test eyes on 10th, 20th and 52nd DPI. Fluorescent positive and cytoplasmic elementary body inclusions (Fig. 2), in both groups till 52 DPI were recorded. All the conjunctiva smears showed some score of Hardey et al. (1967). Low serum titres varying from $1: 4$ to $1: 8$ were recorded (Table 1 ).

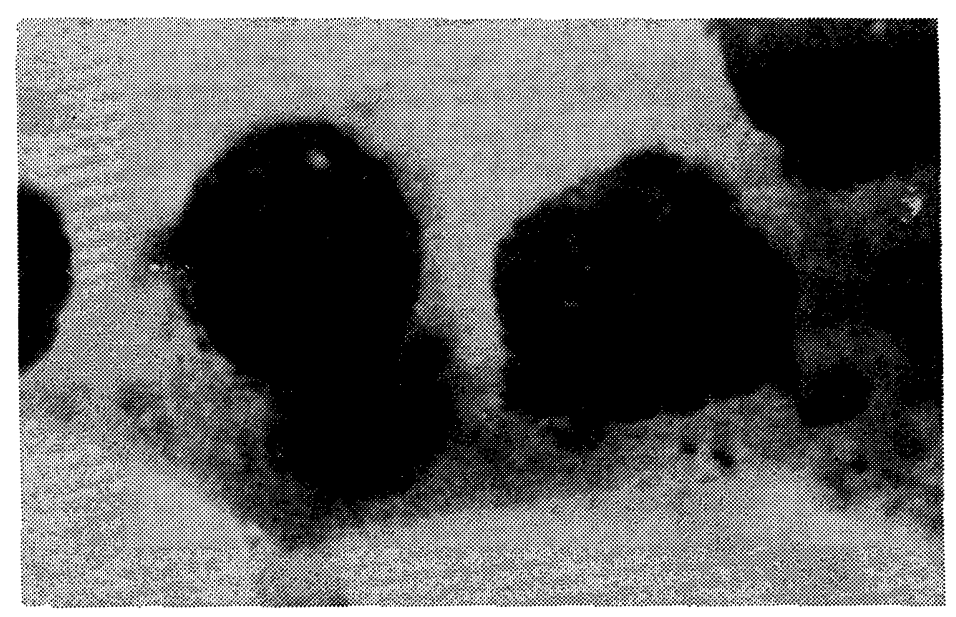

Fig. 2. Conjunctival scrapings showing intracytoplasmic inclusions in a lamb following conjunctival scarification with a strain of Chlamydia psittaci. Giemsa, $\times 1000$.

Table 1

Labo ratory investigations in lambs after conjunctival scarification with three strains of chlamydia

\begin{tabular}{|c|c|c|c|c|c|c|c|c|c|c|c|c|c|}
\hline \multirow[t]{2}{*}{ Organism } & \multirow{2}{*}{$\begin{array}{c}\text { Animal } \\
\text { code }\end{array}$} & \multirow{2}{*}{$\begin{array}{l}\text { Eyes } \\
\text { used }\end{array}$} & \multicolumn{3}{|c|}{ Reisolation days } & \multicolumn{3}{|c|}{$\begin{array}{c}\text { Immunofluorescence } \\
\text { days }\end{array}$} & \multicolumn{3}{|c|}{ Cytology (days) } & \multicolumn{2}{|c|}{ CFT days } \\
\hline & & & 10 & 20 & 52 & 10 & 20 & 52 & 10 & 20 & 52 & 20 & 52 \\
\hline \multirow{2}{*}{$\begin{array}{l}\text { C. trachomatis } \\
\text { (Bour) }\end{array}$} & 1 & $\mathrm{~B} / \mathrm{E}$ & - & - & - & - & - & - & $(2,2)$ & 2,1 & $(-,-)$ & $1: 16$ & $1: 8$ \\
\hline & 2 & $\begin{array}{l}\mathbf{R} / \mathbf{E} \\
\mathbf{L} / \mathbf{E}\end{array}$ & - & $\overline{-}$ & $\overline{-}$ & - & - & - & $\begin{array}{l}(2) \\
(2)\end{array}$ & $\begin{array}{l}(-) \\
(-)\end{array}$ & $\begin{array}{l}(-) \\
(-)\end{array}$ & $1: 4$ & $1: 4$ \\
\hline $\begin{array}{l}\text { C. psittaci } \\
\text { Ocular (cattle) }\end{array}$ & $\begin{array}{l}3 \\
4\end{array}$ & $\begin{array}{l}\mathbf{B} / \mathbf{E} \\
\mathbf{R} / \mathbf{E} \\
\mathbf{L} / \mathbf{E}\end{array}$ & $\begin{array}{l}+ \\
+ \\
-\end{array}$ & $\begin{array}{l} \pm \\
-\end{array}$ & $\begin{array}{l}(x) \\
+ \\
+\end{array}$ & 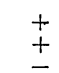 & $\begin{array}{l}+ \\
+\end{array}$ & $\begin{array}{l}(x) \\
\pm \\
+\end{array}$ & $\begin{array}{l}(4,4) \\
(4) \\
(3)\end{array}$ & $\begin{array}{l}(10,3) \\
(10)\end{array}$ & $\begin{array}{l}(x) \\
(3) \\
(-)\end{array}$ & $\begin{array}{l}1: 4 \\
1: 8\end{array}$ & $\begin{array}{l}(x) \\
1: 8\end{array}$ \\
\hline $\begin{array}{l}\text { C. pitttact } \\
\text { faeces (sheep) }\end{array}$ & $\begin{array}{l}5 \\
6\end{array}$ & $\begin{array}{l}\text { B/E } \\
\mathbf{R} / \mathbf{E} \\
\mathrm{L} / \mathrm{E}\end{array}$ & $\begin{array}{l}+ \\
+ \\
-\end{array}$ & $\begin{array}{l}+ \\
+ \\
-\end{array}$ & $\begin{array}{l}+ \\
+\end{array}$ & 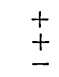 & $\begin{array}{l}+ \\
+\end{array}$ & $\begin{array}{l}-+ \\
-\end{array}$ & $\begin{array}{l}(3,3) \\
(3) \\
(2)\end{array}$ & $\begin{array}{l}(4,4) \\
(4) \\
(1)\end{array}$ & $\begin{array}{l}(10,2) \\
(10)\end{array}$ & $\begin{array}{l}1: 4 \\
1: 4\end{array}$ & $\begin{array}{l}1: 4 \\
1: 4\end{array}$ \\
\hline
\end{tabular}

$+=$ Positive. $-=$ Negative. B/E Both test eyes. $\mathrm{R} / \mathrm{E}=$ Right test eye. $\mathrm{L} / \mathrm{E}=$ Left control eye.

$(x)$ Animal died on 22nd day. 


\section{Discussion}

Of the three eyes inoculated with Bour strain of $C$. trachomatis none showed conjunctival follicles though, congestion was noticed throughout the period of study. Bour strain is considered toxic and it was perhaps the inoculum itself which might have elicited this clinical response. All the laboratory studies were negative except that in one animal where group specific CF antibody titre of $1: 16$ was observed. The pre-test serum of this animal was negative for complement fixing antibodies. It is possible that after scarification of the conjunctiva the tissue barrier could have been broken and the organisms might have reached into the blood. We have no information with regard to any human ocular strain which might have been associated clinically in animal ocular disease. Experimental evidence, however, are available where uveitis in rabbits and monkeys were produced ( $\mathrm{Oh}$ and Tarizzo 1969; Mohan et al. 1977).

Both mammalian strains exhibited initial slight oedema of lids which later subsided. Mild to moderate congestion of conjunctivas and follicles resembling trachoma on both conjunctivas, especially the lower one including the third eyelid were observed. Pannus and keratitis were not seen during the 52 days period of study. The present studies are in partial agreement with Stephens on et al. (1974), who in addition have reported the development of pannus and keratitis in natural cases of lambs. One animal inoculated with ocular stain of $C$. psittaci developed polyarthritis after two months. Reisolation of chlamydia could not be made as the synovial fluid got contaminated. This observation is favourably in agreement with Hopkin et al. (1973) who reported ocular infections in sheep in association with epizootic of polyarthritis. Laboratory studies revealed that reisolation was not a problem, because samples after checking sterility were pooled at each interval and this resulted in $100 \%$ reisolation. It was further felt than conjunctival scrapings obtained from follicular area yielded less contamination. Immunofluorescence studies yielded $80 \%$ conjunctival scrapings to be positive. Cytological studies showed very low inclusion positive conjunctival scrapings $(25 \%)$ in both groups. However, all the conjunctial scrapings exhibited some numerical score suggestive of probable chlamydial infection (Hardy et al. 1967).

The study therefore makes the following observation on record that both the strains of $C$. psittaci have no tissue barrier and produced conjunctival follicle in lambs. Bour strain of $C$. trachomatis like other strains has no innate ability to infect across tissue barriers in lambs. Laboratory studies revealed that reisolation (pooled samples) alone or immunofluorescence coupled with positive serology or cytology should be considered diagnostic for ocular chlamydial infections.

\section{Experimentálně vyvolaná oční chlamydióza u jehňat}

Do konjunktiválního vaku jednoho oka zdravých jehňat bylo instilováno $0,2 \mathrm{ml}$ kultury dvou lokálních kmenů Chlamydia psittaci izolovaných z ovcí a skotu a Chl. trachomatis (kmen Bour). Každou kulturou byla infikována dvě zviŕata. Klinické a laboratorní sledování po infekci trvalo 52 dnů. Kmen Bour nevyvolal u jehňat infekci spojivek, avšak oba kmeny Ch. psittaci způsobily tvorbu folikulů na spojivce dolního i horního vička během $1-4$ týdnů po infekci. Nebyla pozorována keratitida ani pannus. Laboratorní testy zahrnující reizolaci, fluorescenční barvení, cytologii a serologii byly negativní u kmene Bour, ale pozitivní v průběhu sledováni infekce oběma kmeny $C h$. psittaci. 


\section{Экспериментапьно вызванный гпазной хламидиоз ягнят}

В коньюнктивальный мешок одного глаза здоровых ягнят вводили 0,2 мл культуры двух локальных штаммов Chlamydia psittaci, изолированных у овец и крупного рогатого скота, и Chl. trachomatis (штамм Bour). Каждой культурой инфицировали двух животных. Клинические и лабораторные исследования после инфекции длились 52 сүток. Штамм Воur не вызвал у ягнят коньюктивит, однако оба штамма Ch. psittaci вызвали образование фолликулов на соединительной оболочке нижней и верхней век в течение 1-4 недель после инфекции. Кератита ни паннуса не наблюдали. Лабораторные тесты, включающие реизоляцию, флуоресцирующее окрашивание, цитологию и серологию, у штамма Bour были негативне, однако они стали позитивными в ходе исследования инфекции с использованием обоих штаммов Ch. psittaci.

\section{References}

BOVARNICK, M. R. - MILLER, J. C. - SYNDER, J. C.: The influence of certain salts, amino acids, sugar and protein on the stability of rickettsiae. J. Bact., 59, 1950: 509-522

HARDEY, D. - SURMAN, P. G. - HOWARTH, W. H.: System of representation of cytologic features of external eye infecitons with special reference to trachoma. Amer. J. Ophthal., 63, 1967: $1535-1537$

HEKBERT, C. A. - PITTMAN, B.-MCKINNGY, R. M.-CHERRY, W. B.: The preparation and physiochemical characterisation of fluorescent antibody reagents. U.S. Department of Health Education and Welfare Health Services and Mental Health Administration Centre for disease control. Atlanta Georgia. 1972

HOPKIN, J. B.-STEPHENSON, E. H.-STORZ, J.: Conjunctivitis associated with Chlamydial polyarthritis in lambs. J. Amer. Vet. Med. Ass., 163, 1973: 1 157-1 160

KAWAMURA, A. Jr.: Fluorescent antibody technique and their applications. Univ. of Tokyo Press, Univ. Park Press, Baltimore, Maryland, Manchester, England 1959

LENNETTE, E. H.-SCHMIDT, N. J.: Diagnostic procedure for viral, rickettsial and chlamydial infections. 5th ed. American Public Health Association, Washington, 1979

OH, J.-TARIZZO, M. L.: Ocular lesion induced by trachoma agent in rabbits. J. Bact., 97, 1979: 1 042-1 044

MOHAN, M. - PRABHAVATI, A. - ANGRA, S. K.: Tric (Chlamydia) keratitis and uveitis An experimental study in monkeys East. Arch. Opthal., 5, 1977: 143-147

SCHACHTER, J.-OSTLER, H. B.-MEYER, K. F.: Human infection with the agent of feline pneumonitis. Lancet, 1, 1969: 1 063-1 065

STEPHENSON, E. M.-STORZ, J.-HOPKIN, J. B.: Properties of frequency of isolation of chlamydia from eye of lambs with conjunctivitis and polyarthritis. Amer. J. Vet. Res., 163, 1973: $1157-1160$ 